\title{
Millennial Democracy and Spectral Reality in Post-colonial Africa
}

\author{
Basile Ndjio*
}

\begin{abstract}
One could not pertinently speak about the recent experience of multi-partyism in Africa without acknowledging the 'teleological meta-narratives' of democracy. That is, a system of knowledge and a series of discourses, theories and ideologies that were constructed around the very idea of political liberalization, and that helped to frame its principles, as well as to orientate its form, expression, mode of functioning and representation. But whatever their orientations, assumptions or theoretical oppositions, all these savoirs shared the same messianic approach to democracy and the same uni-linear evolutionist vision about the social and political adjustment which many African countries were going through in the early 1990s. Indeed, political liberalization, as envisaged by both developmentalist and modernist philosophies, assumed not only the universal principle of elective representation, good governance, freedom, fair competition and alternation, but also embraced the enlightenment ideals of emancipation, progress, change and betterment.

In this contribution, which does not claim to assess the experience of democracy in sub-Saharan Africa, we want to examine how these grand narratives have affected Africans' imaginations and the way they represent multi-party politics, and how, as a result of these millenarian ideologies, many of them have transformed the political adjustment into a sort of mythology of redemption. However, what is much more important to us is to demonstrate that modernist (developmentalist and evolutionist) formulations of the democratization process of the early 1990s, as a simple replica-
\end{abstract}

* Basile Ndjio teaches Social and Political Anthropology at the University of Douala in

Cameroon.Email:ndjio23@yahoo.fr 
tion of western modernity, have failed to take up the conceptual and methodological challenges which these theories encountered when they travelled from the West to sub-Saharan Africa.

\section{Résumé}

On ne saurait parler avec pertinence de l'expérience récente du multipartisme en Afrique sans reconnaitre les «métarécits téléologiques » de la démocratie. Il s'agit d'un système de connaissances et d'une série de discours, de théories et d'idéologies qui ont été construits autour de l'idée même de la libéralisation politique, et qui ont permis de formuler ses principes et d'orienter sa forme, son expression, son mode de fonctionnement et de représentation. Mais quelles que soient leurs orientations, leurs hypothèses ou leurs oppositions théoriques, tous ces savoirs partageaient la même approche messianique de la démocratie et la même vision unilinéaire évolutionniste sur l'ajustement social et politique que de nombreux pays africains subissaient au début des années 1990. En effet, la libéralisation politique, comme envisagée par les philosophies développementaliste et moderniste, a non seulement adopté le principe universel de la représentation élective, de la bonne gouvernance, de la liberté, de la concurrence loyale et de l'alternance, mais a aussi épousé les idéaux d'émancipation, de progrès, de changement et d'amélioration du siècle des lumières.

Dans cette contribution, qui n'a pas la prétention d'évaluer l'expérience de la démocratie en Afrique sub-saharienne, nous voulons examiner comment ces grands récits ont affecté les imaginations des Africains et la façon dont ils représentent les politiques multipartites, et comment, du fait de ces idéologies millénaristes, nombre d'entre eux ont transformé la politique d'ajustement en une sorte de mythologie de la rédemption. Cependant, ce qui est beaucoup plus important pour nous, c'est de démontrer que les formulations modernistes (développementaliste et évolutionniste) du processus de démocratisation du début des années 1990 comme une simple reproduction de la modernité occidentale n'ont pas réussi à relever les défis conceptuel et méthodologique auxquels ces théories ont été confrontés quand elles ont voyagé de l'Occident vers l'Afrique sub-saharienne.

\section{Introduction}

In November 2003, I attended a political rally organized at the Douala Reunification stadium by two main opposition parties in Cameroon (the Social Democratic Front and Cameroon Democratic Union). The objective of the meeting was to explain to their supporters their recent alliance in preparation for the presidential election which was then scheduled to be held on 11 October 2004. Before a meagre crowd who seemingly 
was much more interested in the performance of nearly denuded young female dancers who were spinning their backsides and wriggling their hips to the rhythm of Makossa and Mdombolo, the Chairman of the Social Democratic Front (the main opposition party in Cameroon) expressed his disappointment about people's loss of interest in politics. He was particularly concerned with what he called 'Cameroonians' indifference and insensibility to the desperate condition the ruling CPDM (Cameroon People's Democratic Movement) regime has plunged many of them into.' Commenting on this failure of the opposition coalition to win popular support to its cause, the editor of the newspaper Le Messager observed that many Douala city dwellers preferred to attend to their daily business rather than waste their time listening to politicians who had got them used to their double-speech and 'compromise of principle' (compromissions). ${ }^{1}$ This setback was reminiscent of a flop experienced in March 2003 by the Togolese opposition, which failed to mobilize its sympathizers for a general strike. Its call for a civil disobedience followed the decision of the Parliament to concede to the nearly 40 yearruling President (Gnasimbé Eyadema) the right to stay à vie in power, or at least to die in power, ${ }^{2}$ as many of his Cameroonian, Gabonese, Burkinabe, Zimbabwean, Equatorial Guinean, Chadian, Guinean, Congolese, Libyan, Egyptian and Tunisian counterparts also wish. Undoubtedly, very few people were willing to take to the streets to challenge the man whom Togolese derisively called 'the Bull of Kara' (Taureau de Kara) and his horde of 'bleeders' (saigneurs). ${ }^{3}$

These two examples are far from being isolated cases. If one acknowledges the present general disaffection of the large majority of Africans with politics, as many have been disappointed with the mythology of democracy (Comaroff and Comaroff 1993; Hermet 1998; Jaffrelot 2000; Njamnjoh 2000:1-44), they constitute a typical case for any study of the experience of the democratization process in contemporary Africa. Indeed, when we observe today the political landscape in most African countries, there is one truth that emerges as the most memorable of any acknowledgment one can make, whether about the esprit militant of Africans ${ }^{4}$ or about their relationship with their political elites: the days are gone when thousands of people willingly crammed into the football stadiums or the main squares of the towns just to listen to the flights of fancy of the opposition leaders, and their usual recriminations against those in power they generally described as tyrants and kleptomaniacs. We have to admit that we are also now far away from the golden time of 
the democratization process of the early 1990s when a determined crowd of young 'freedom fighters' and 'combatants' could defiantly take to the streets and ask for the organization of a Sovereign National Conference, a sort of popular tribunal where the despots and their cliques would be judged for their crimes. The former heroes have become the true 'zeros,' or are fatigués, as one Cameroonian newspaper derisively put it. ${ }^{5}$

The rebirth of the multi-party system in many African countries in the early 1990s, or what came to be known as the democratization process, was of particular interest to policy makers, politicians, subaltern groups, and especially social thinkers. For the former, the demand for democracy or 'authoritarian decompression' (Bayart 1993) corresponded with the pervasive developmentalist ideology of the late 1980s, and the insidious policy of guardianship and supervision of the black continent by 'experts' of the IMF and World Bank. ${ }^{6}$ Indeed, the ideal of democracy and good governance, as forecast by some gurus and apostles of neo-liberal policy was considered a panacea that supposedly had the magical power of turning the highly indebted poor African countries into newly-developed countries like the six dragons of South-eastern Asia or would at least help ill-governed African states and their despotic rulers achieve what O' Donnell and Schnitter (1999) call 'transitions from authoritarian rule'. That is why for lack of being what Hermet (1998) has called 'democrats by conviction,' African obscure despots, then in power, were forced to be or become 'democrats by convenience.' Had they any choice, since access by their impoverished and cash-strapped countries to foreign aid was conditional on their adoption of the newly fashionable notions of liberalization, democracy, good governance, and structural adjustment?

For political elites, notably the ruling classes, this new mode of governmentality called 'democracy' was seen as an opportunity to formulate new strategies of domination and accumulation, or simply to restructure old formulas of authority built on other foundations, logics and imaginaries (Mbembe 1993:345-74, 1990:7-24; see also Politique Africaine 1991). As will be discussed in this paper, it is all this 'capacitybuilding' or bricolages that later enabled African rulers to reinforce their hegemonic position over their subjects.

As regards the subaltern groups, which welcomed the rhetoric of political changes with excitement which sometimes bordered on fanaticism, the democratization process was rather looked upon as the embodiment of the historical perspective to dissent from the postcolonial rule. Moreo- 
ver, many of them equated this process with the prospect to deconstruct the social and political order that made possible the maintenance of the prevailing ignoble system, and its continuation over the longue durée. In other words, for many Africans, the restoration of the multi-party system represented the dreams of getting rid of their despotic, predatory and kleptomaniac regimes (Monga 1995:359-79; Mpom 1994).

Yet one could not pertinently speak about the experience of multipartyism in post-colonial Africa without acknowledging or mentioning what I call after James Ferguson ${ }^{7}$ the 'teleological meta-narratives' of democracy. By this expression, I mean a system of knowledge, and a series of discourses, theories and ideologies that were constructed around the idea of political liberalization in Africa, and that helped to frame or systematize its principles, moreover to orientate its form, expression, mode of functioning and representation (Nyang'oro 1994). But whatever their orientations, assumptions, tenets or theoretical oppositions, all these savoirs shared the same messianic approach to democracy and the same uni-linear evolutionist vision about the social and political adjustment many African countries were going through in the early 1990s. Indeed political liberalization, as envisaged by both developmentalist and modernist philosophies, assumed not only the universal principle of elective representative, good governance, freedom, fair competition and alternation, but also embraced the enlightenment ideals of change and betterment. Neo-liberal ideologues held multi-party politics and democracy up as a condition sine qua non to any sustainable advancement in the economic, social and political domains in Africa. That is why, the catchphrase that western maittres-penseurs regularly repeated to their African pupils was: 'No development without democracy.' The reason was that democracy and liberal politics suggested for these self-proclaimed 'visionaries' the end of corruption, nepotism, patrimonialism, favouritism, clientelism, dictatorship, etc. in Africa. But what was pervasive in these modernist meta-narratives of democracy was the naivve certainty that the ongoing democratization process would move African countries from an old system to a New Age: from crisis to progress, backward societies to modern nations, stagnation to sustainable growth, etc (World Bank 1989). The optimistic and sometimes excessive account of the democratization process in many sub-Saharan countries indicated the extent to which what some analysts hastily called the 'second decolonization', or 'African revolution' (Kamto 1997:177-95) had captivated the modernist thought of the early 1990s. 
In this contribution, which does not claim to assess the experience of democracy in sub-Saharan Africa, I want to examine how these grand narratives have affected Africans' imagination and the way they represent multi-party politics, and how as a result of these millenarian ideologies, many of them have transformed the political adjustment into a sort of mythology of redemption. However, what is much more important to me is to demonstrate that modernist (developmentalist and evolutionist) formulations of the democratization process in Africa as what Comaroff and Comaroff (1999:27) call a 'replay of euro-capitalist modernity' have failed to take up theoretical and methodological challenges that these theories encountered when they travelled from the West to the post-colonial Africa. Moreover, 'the fault of analytic hurry' which, according to Callaghy (1994:248), is the weakness of most Africanists, has prevented them from paying attention to: (1) the amazing ability of African rulers to adapt to modern changes; (2) their inventive spirit, and their art of resourcefulness and hustling; (3) their skill at regaining control over people and local spaces through the manipulation of the collective memory, and the reactivation of ethnic, regional, religious and parochial solidarities; (4) their capacity to reformulate the old modes of accumulation and domination and redistribution of state resources; (5) their talent for 'capturing' their political opponents; (6) their gift for transforming the political adjustment into a despotic adjustment, etc. In short, what I want to stress in this paper is the ability of African autocrats to invent their own democracy. What the African popular imagination now derisively refers to as 'the rule by military' (militocracy), 'ethnodemocracy' (ethnocracy) or 'democracy of the mouth and belly' (mangecratie) is the product of the African genius.

I will use the Cameroonian case to illustrate this form of demo-cracy that has become the constitutive dimension of many African regimes' mode of governance. Cameroon's experience is interesting for several reasons: first, right from the beginning, the experience of the multi-party system in this country has been simply downgraded to a sheer struggle for power, or has taken a Manichean pattern of good and evil. Second, Cameroonian demo-cracy, ${ }^{8}$ as I will be discussing in the following pages, is the archetype of these new forms of kratos (powers) that today sustain both the hegemonic and accumulative project of the dominant classes in sub-Saharan Africa. These new forms of domination which emerged for the most part in the early 1990s are often translated by disenchanted but nonetheless humorous Africans, and notably Cameroonians as 
ethnocracy, warlord-cracy, kleptocracy, poverty-cracy, NGO-cracy, AID-cracy. All these systems or dispositifs, to use Foucault's words (1979), enable a handful of people (whether from the ruling class, the opposition or the so-called civil society) to maintain their dominant position, thanks to their control over state resources and international donations. ${ }^{9}$ Last but not least, this country exemplifies Africa's 'fiddle system of democracy' (traficotage de la démocratie). It also gives a good illustration of the ability of the Biya regime to defraud democratic principles, outwit or mislead international organizations (Banoch 1992; Mbarga 1993; van der Walle 1990). I will focus my analysis on what the official rhetoric in Cameroon has initially called 'advanced democracy' (démocratie avancée), and then 'pacified or appeased democracy' (démocratie apaisée), not only to give an insight into this Cameroonian system of gouvernorat, but also to decode a routinized procedure that since 1991 has been mediating the relationship between the ruling CPDM regime and the civil society at large in this country.

\section{Democratization Process: The Power of the Sans-culottes}

In many respects, the experience of political liberalization in Cameroon was distinctive from what many African countries were going through in the early 1990s. This singularity could be related to a number of factors: the strong opposition of the conservative ruling class to what its members perceived as an adventure and a great threat to the stability of the country and the national unity; the violence and uncertainty that paved the way for its birth, and continues even today to impinge on its practices and modes of expression; the tragedy and disaster it brought about; the bloodshed and deaths that macadamized its path; the fervour and enthusiasm it aroused; the energy and strength it mobilized; the radicalism and fanaticism it led to; the ethnic withdrawals and parochial solidarities it exacerbated, the confusion and upheaval it created; the dreams and expectancies it stimulated, and finally the disappointment and frustration it gave rise to.

In some other African countries, the democratization process came about as a result of arrangements between different groups of interests ${ }^{10}$ willing to remodel the absolutist authoritarian state. However, in Cameroon the political liberalization rested neither on any deal between the ruling CPDM party on the one hand, and the opposition movement and the civil society on the other hand, or between the holders of political power and ordinary people (Courade and Sindjoun 1996; Gros 2003; 
Sindjoun 1996:27-51; Sindjoun and Owona 1997:217-45). Nor did it emerge as the consequence of an agreement between these social protagonists to 'good-govern' the Cameroonian society, at least to set up a political public sphere where free citizens and 'autonomous public body,' to use Habermas's expression (1989:145, 1984), could enjoy a freedom of speech, assembly, movement, etc. It is not exaggerating to say that in Cameroon, the demand for political liberalization rather engendered a misunderstanding between the pro-democracy movement and the conventional CPDM regime, which was reluctant to give up its unlimited privileges and monopolistic rights to the state resources (Monga 1998).

While the pro-opposition movement and the population from the grassroots welcomed the democratization process and the upsurge of the oppositional policy as promising social and political transformations, the conservative Biya regime rather viewed them as threatening and dangerous for its maintenance in power. This dissension was all the more exacerbated by the CPDM government's strong belief that there was no need to adopt the multi-party system so passionately claimed by prodemocracy activists because since 1985, the country had had democracy and freedom of expression within the ruling CPDM party whose Chairman - who is also the Cameroonian Head of State - once described it as a 'democratic and liberal party open to all trends'. ${ }^{11}$ As a result of this professed dogma which claimed a divine truth beyond dispute, any overt attempt to oppose the deification of the Head of State, the man who allegedly was in power by the grace of God, ${ }^{12}$ or any vague desire to found a political party was automatically understood as an act of subversion, public order offence and even breach of national security: a 'crime' which in the context of authoritarianism was liable to a life imprisonment or death penalty. Fortunately, the resistance to multi-party politics vanished when, under increasing domestic difficulties and foreign pressures, notably from France and international organizations (IMF and the World Bank), the Biya regime was forced to decompress the former authoritarian one-party system.

But the political adjustment that the conservative Biya regime finally conceded did not put an end to the disagreement between the ruling party and the opposition movement which imagined change and democracy in Cameroon differently. Indeed, for all these young men and women who from May 1990 onwards heroically entered into rebellion against the authoritarian 'Regime of New Deal' (Regime du Renouveau), as the ruling CPDM regime is officially designated, or courageously voiced their 
exasperation against the Father of the Nation, the new era called 'age of democracy' was the time of defiance and insubordination. It signalled a resistance against a system which, for over 30 years, had silenced people or fossilized their thought, and an opposition to a form of governance that transformed citizens into mere subjects. The social protest movement that came to be popularized in Cameroon as 'ghost town operation' (opération villes mortes) exemplified both the aesthetics of indiscipline and subversion, and the front of refusal instigated by the opposition movement. This 'ghost town operation,' which Cameroonians experienced between 1991 and 1993, was a collective action that engaged subaltern groups in a ritual of deconstruction of the established authority, or in the process of what Bayart (1993:247) calls 'de-totalization of power.' If in some regions of the country the social movement was peaceful and well organized, in other areas, it rather degenerated into a culture of riot that often led to violent confrontations between security forces and pro-democracy activists, most notably young 'freedom fighters' and 'combatants'.

However, the most remarkable feature of this deconstructive process was the shift from what James Scott (1990) calls a 'hidden transcript' of resistance, which was the main characteristic of the mode of dissidence of the past, to an overt or public practice of indiscipline and subversion: truth was no longer spoken behind the backs of the officials as people used to in the old days, but rather to their face. The practice of insubordination was no longer concealed or disguised through rumours, slander, gossip, jokes and dissimulation which insinuated a critique of the dominant classes, while hiding behind anonymity and malice, but was rather publicized through popular songs or music, paintings, graffiti on the walls, newspaper articles or cartoons, etc (Monga 1997:146-69; Nyamnjoh 1999:93-106). Power incarnated by the figure of the despot or what the man in the street calls the 'Lion-man' (L'Homme-lion), was depicted in the popular literature as bestial, ferocious, murderous, sadistic, malevolent, diabolic, etc. Sometimes, it was sketched as voracious, greedy and grotesque (Mbembe 2001; Ndedi Penda 1992). For the young 'freedom fighters' and 'revolutionaries' who were at the forefront of what I have elsewhere called 'the practice of ungovernmentality' (Ndjio 2002), this devilish power which was 'eating' the state or starving Cameroonians, deserved nothing but a red card that would send it off. To the best of my knowledge, it was the first time in the history of this post-colonial state that the ruler was publicly questioned, shouted at, vilified or slandered: 
'Who is the thief? Paul Biya' (Thief man na wou? Paul Biya); 'people are suffering, while Paul Biya enjoys a happy life' (People di sofa, Paul Biya di chop moni), yelled the protesters vociferously and defiantly as they took to the streets in Douala and Yaounde (the main cities of Cameroon) and in other cities of the country.

From mid-1990 up to the late 1993, the daily performance of what James Scott (1990:18) calls the 'infrapolitics of the subordinate groups' was reduced to the rudimentary action of desecrating the state power, but above all of symbolically killing the despot. People did it by defiling his countless doubles (images), which generally invaded the public space, or by turning them into objects of derision and laughter. In some cities or towns of the country where the experience of the ghost town operation was most dramatic, young people expressed their anger by taking it out on the Head of State's giant portraits, after a violent clash with the forces of law and order: they would put out the President's eyes on his images with points or nails, pour drinks on his face, tear his picture up and use it as toilet paper, or coat his face with their excrement. This provocation could go further when the offenders in a general frenzy would simply cut his head off. It seems as if through these symbolic acts, these 'delinquents' wanted to drive the 'Father of the Nation,' his cumbersome phantoms and harmful totems (images) out of the public domain. In many respects, this practice of ungovernmentality went along with the culture of 'pleasure' (jouissance) that entailed above all new uses of bodies, new forms of desire and happiness, or new ways of living and dying (Ndjio 2005:265-94). Thanks to this Dionysian culture, the postcolonial subjects found themselves engaged in a moral 'economy of ejaculation' (de Boeck 1998:790), which exalted vicious pleasure, drunkenness, debauchery and lechery, or made the apology of ludicrousness, obscenity and vulgarity. In this world of ecstasy and fantasy, the public space itself became a site of invention of new forms of indiscipline and indocility that primarily resorted to a popular use of sex and body as a privileged mode of challenging established logics that guided the post-colonial public sphere (Ndjio 2005:277-8).

Another important aspect of the 'ghost town operation' is that it prompted the emergence of a 'collective will of people' (Foucault 1991, 1979), whose action was less motivated by what some analysts simplistically call the 'logic of clientelistic and patrimonial reciprocity' (Chabal and Daloz 1999:37-39) than their will to pull down one of the most conservative and corrupt regimes in Africa. Through this revolutionary 
project, the newly emerging 'civil society' (see Kamto 1997:177-95; Monga 1998) plotted the elaboration of a 'counter-memory' of the postcolonial state, as Michel Foucault (1979) would have put it. Moreover, it attempted to reverse or undermine what I call, after Gayatri Spivak (1985:342) the official 'historiographic metalepsis' which sanctified the postcolonial ruler and his power. For example, when the despot made himself appear as the 'Incarnation of Rigour' (L'Incarnation de la Rigueur), 'Father of the Nation' (Père de la Nation), 'Providential Guide' (Guide Providentiel), 'Grand Helmsman' (Grand Timonier) or 'Apostle of Peace' (L'Apôtre de la Paix), the popular imagination mischievously misrepresented him as 'the incarnation of the Cameroonian predicament' (Incarnation du mal Camerounais), 'bogeyman' (père fouettard) or 'big thief' (chef bandit). When the governmental propaganda boasted the incumbent regime as 'advanced democracy' (démocratie avancée), the commoners strongly believed that they were instead experiencing 'advanced autocracy' (autocratie avancée). November 1982, which, according to official exegetes signalled the beginning of a new age called the era of 'rigor and moralization' (rigueur et moralisation), was rather interpreted by the subaltern groups as the birth of tragedy, the debut of suffering, despair and demoralization.

However, the main singularity of this newly constituted civil society was its capacity to transcend parochial solidarities and ethnic boundaries, and to rise above the 'politics of the belly' (Bayart 1993). As far as one can go back to the history of the post-independent Cameroon, it was the first time that political actions were driven less by the 'need to acquire the patrimonial means of one's political legitimacy' (Chabal and Daloz 1999:37) than a powerful utopia that united common people against their rulers: 'change' (changement). For the pro-democracy movement, change meant, not only normalizing the political situation in the country but also changing the existing political order, the method of government together with the renewal of the political leadership. The holding of the Sovereign National Conference, that many people were insistently asking for, ${ }^{13}$ embodied the project to reframe the postcolonial state, to restore a state of law or to transform the way of making politics in this country (see Eboussi Boulaga 1993; Kamto 1997:177-95; Sindjoun and Owona 1997:217-45). Even a cursory and superficial examination of the opposition movement of the early 1990s would corroborate that its radicalization, notably between 1990-1993, ${ }^{14}$ and the culture of riot and martyrdom it engendered, left no room for political 
calculus, clientelistic transactions or dealings with the ruling CPDM regime. Indeed, the period of 'ghost town operation' (1991-1993) inaugurated an era when political elites, especially those who were connected to the opposition primarily drew their legitimacy and prestige, not from their aptitude at building up clientelistic and patrimonial networks from the local to the national level, but rather from their radicalism and fierce opposition to the incumbent regime. The more intransigent and extremist an opposition leader was, the more popular. At that time when the relationship between the governmental coalition and its opposition was dominated by the dynamics of hostility and confrontation, colluding with the scornful CPDM regime was equivalent to political suicide. While for the CPDM leaders, making any concession to the opposition was likely to be interpreted by their sympathizers as a weakness and lack of authority; those politicians (whether from the opposition or the ruling party) who transgressed this principle endured a political setback from their supporters.

There are many former prominent opposition leaders who lost popular support, and even undermined their political careers, just for having played what James Rush (1990) aptly calls 'the dance of collaboration' with the incumbent CPDM regime. In many respects, collaborating with the CPDM government or practicing the 'politics of the belly,' meant accepting a ministerial or administrative post, or 'eating the CPDM's 'dirty money' (argent sale),' as one local newspaper once formulated (see Le Messager, 25 June 1994). What came to be popularized in the country as toum man embodied the figure of the traitor who 'goes over to the enemy'. A toum man was not only a 'chameleon-politician or turn-coat politician' (politicien caméléon), a 'political nomad' (transhumant politique) or a 'political prostitute' (prostitué politique) who switched from one party or client to another, but also a renegade who gave up his commitment or who betrayed a good cause for personal interests (Challenge-Hebdo 21 June 1991). But what did the mythology of democracy and political liberalization mean for these young men and women who everyday were clashing with the police and gendarmes, and at the very worst were shot dead?

\section{Democracy and Collective Fantasies}

We cannot dissociate the call for democracy that gripped almost the entire African continent from the mythology that the democratization process embodied from the very beginning, or from the dreams and utopias that multi-party system came to incarnate in the early 1990s. Nor 
could we have a better understanding of the experience of political liberalization in this part of the world, unless we pay attention to what Comaroff and Comaroff (2000:330) cogently call the "millennial optimism' and the gospel atonement with which multi-party politics was associated. Indeed, this messianic vision that spread all over the Black continent in the early 1990s invested the liberal politics with the capacity to transform the living conditions of marginalized Africans who were caught in the nets of dictatorship and authoritarianism. In a context essentially marked by wretchedness and anxiety, liberal democracy presented itself to the powerless and other second-class citizens as a millennial project that provided them with optimism, self-confidence and positive expectations for their future. Only the acknowledgment of the enthusiasm and exuberance with which many Africans in general, and Cameroonians in particular, welcomed the restoration of multipartyism in their country, could inform us about the perspective to achieve through the democratization process the eagerly awaiting '30 glorieuses' that an unachieved de-colonization had relegated to what Denis Jeambar rightly calls '30 ignominieuses' 15 .

This redemptive narrative of both democracy and multi-party politics influenced even the dynamic popular culture, which became by the end of 1990 the vivid expression of the general faith that suffering, poverty and distress, which were commonplace for ordinary Cameroonians, would soon be forgotten. Take, for example, cartoons caricatures and sketches that were extremely popular in the early 1990s (Monga 1997:146-69; Njamnjoh 1999:93-106). Most of these figurative expressions, which regularly appeared in pro-opposition newspapers, did not content themselves with narrating the social drama experienced by many Cameroonians. They also imagined a free, egalitarian and prosperous society that contrasted with the prevailing inhuman and vicious society. In many respects, the democratic Cameroon, about which this popular culture fantasized, was a society where broken subjects became the masters of their own destiny; where tamed bodies slowly moved from the process of crucifixion to that of resurrection and redemption, from social alienation and abjection to social promotion, from a spectral condition to a pleasant one, etc. In this fantastic world projected in satirical newspapers such as Le Messager Popoli, Challenge-Hebdo, Porc-epic or Mami Wata, the 'sovereign people' seized (or could seize) the power, got the autocrat arrested, and dragged him by force before a popular assembly presided over by leaders of the opposition and pro-democracy activists; 
they would force him to give back the money he had stolen from the people (see also Mbembe 2001:149-53).

Another example of this imagined society are furnished by Lapiro de Mbanga's well-known songs, Mimba we (Remember us) and Don lefam Tara (Don't give up my friend) that enchanted the slum dwellers of New Bell in Douala or Madagascar and Briqueterie in Yaounde, or AnneMarie Ndzié's famous freedom chant, Liberté, that became the rallying song of many young 'freedom fighters' who regularly took to the streets during the period of 'ghost town operation' and civil disobedience campaigns of the early 1990s. These chants attracted people, not only because they enabled the populace to be serene in the face of tragedy and affliction inflicted on them by the 'Regime of New Deal' but also because they conveyed powerful messages of courage, resourcefulness, hope, optimism and self-reliance. In short, they prophesied a better tomorrow for the underprivileged and the powerless. No surprise then that prodemocracy activists and opposition members who challenged the security forces daily chanted these popular freedom songs each time they endured police brutality: 'No condition is permanent in this world; one day, one day situation must change in this country, 'Liberty, liberty, thanks to Mighty God, at last we are free' (Liberté, liberté, Dieu Tout-Puissant, nous sommes enfin libres merci). ${ }^{16}$ No wonder that militants of the Social Democratic Front translated their party's acronym as Suffer Don Finish (Suffering is over). By this, they meant that the institution of the multiparty system would put an end to the kleptocratic and corrupt 'Regime of New Deal', once described as a regime whose main goal was to 'make Cameroonians become definitely poor', to quote one young motorbiketaxi driver from Douala.

Yet, for all these enthusiastic and fanatical opposition supporters, this mythology of political liberalization was not simply a matter of liberty, good governance, freedom of expression and assembly. It conveyed above all a redemptive promise that was manifest in the ideal of 'change' (changement), as Cameroonians called it. The quest for change was not only the main obsession of many of them. It was also what they were fighting for, and were even ready to die for: people courageously took to the streets and asked for the resignation of the 'Father of the Nation,' because they wanted change; they defied the state authority because of 'change'; they challenged the established logics that guided the postcolonial public sphere for the same purpose. Between 1990 and 1993, the only political discourses that interested people were precisely those 
that echoed their expectations of change, or those that promised them a new beginning. At that time when everybody was obsessed with the idea of 'change' and that all political debates were centred on this matter, ${ }^{17}$ the opposition movement had nothing on its political agenda but the achievement of this change. The term 'change' was so fashionable that none of its leaders could end his/her speech without referring to this magical theme or giving a pledge to 'make things change in the country': a commitment that generally stirred up thunderous applause from the crowd. How could it be otherwise when the more convincing discourses of that epoch were the most radical ones, or those that emphatically advocated the replacement of the ever-lasting Biya regime? In addition, acknowledging the dedication of the pro-democracy movement to change, it seems as if the struggle for democracy that mobilized many Cameroonians at that time was simply the fight for change in this country. No wonder that the coalition of the opposition parties was called the 'Union for Change' (Union pour le changement), and that all pro-democracy activists were dubbed the 'Front Allies for Change' (Fronts alliés pour le changement), in opposition to the CPDM barons who were disdainfully labelled the 'Conservative Forces or Opposition to Change' (Forces conservatrices ou de l' immobilisme). But the question one may ask here is: why were people so obsessed with the idea of changement? Why did the quest for a democratic society come to be simplified or narrowed to a struggle for change?

The answer might be that, this fantastic ideal of 'change' touched the imagination of the population at large, because it augured the return to the fatherland of thousands of Cameroonian nationalists who had been forced to go into exile by the authoritarian regimes of Amadou Ahidjo, and his successor Paul Biya. Moreover, the dream of 'change' revived the old nationalist aspiration to create an egalitarian society, or to make Cameroon 'a land of hope and happiness' for all Cameroonians, and not an archipelago of injustice and despair (Joseph 1977; Mbembe 1996; Um Nyobe 1989, 1984). However, many people came to associate the democratization process with that of 'change' because the latter supposedly would change people's desperate living conditions. As a market woman from the Douala central market explained in the local newspaper, Challenge-Hebdo,

The changement will bring job and money to people. People will no longer endure poverty and suffering. Everyone will live a better life like when the Kassa'a (she meant the former President Amadou Ahidjo) 
was in power. Not that some eat alone, while others have nothing to eat. This is not fair. We want change in this country. ${ }^{18}$

The lady's opinion reminded me of the snatches of conversation I picked up by chance in April 1991 between two middle-aged men who were hotly discussing in a bar in New Bell, the most populated district of Douala. In reaction to his partner who wondered why the word 'change' was on everybody's lips,' one of the two who was named Tagni said that it was because "the changement would prevent Paul Biya and his cliques from stealing people's money and keep it in the banks in Switzerland.' He added that, the coming 'change' would send all the 'thieves' (thiefmans) to prison, if they did not give back all the money they had embezzled. But his friend who was rather sceptical, questioned whether 'the 'change' would bring a real change in the country,' and whether once in power, 'the opposition leaders would not misappropriate the public funds or deprive too the populations from their money as CPDM dignitaries did.' Tagni's response was that the opposition could not replicate the former predatory system because 'the changement would give power to people and not to longs crayons' (educated elites).

These different statements only expressed a collective fantasy that transformed the ideal of change into a panacea that would solve any existential problem the natives were confronted with, a cry of 'Open Sesame' that had a magic power to make even the impossible become possible. In many respects, the holding of a SNC (sovereign national conference) that people were insistently asking for would assumedly bring about the eagerly awaited great transformation, or "would make the real change possible in the country,' as one leader of the opposition movement explained in a local newspaper (L'opinion, 6 June 1991). That is why by March 1991, 40 opposition parties (out of 47 political parties that were registered at that time) formed a coalition which main goal was to compel the ruling CPDM regime to convene a SNC, which was proclaimed mandatory for the country. However the conservative President declared it 'baseless,' because he strongly believed that his regime was already a well-established democratic system, and therefore needed no transitional government, much less the holding of a SNC. Thus, the general civil disobedience and the protracted and devastating 'ghost town operation' of the early 1990s aimed at forcing the reluctant CPDM government to concede to their demands for a SNC.

For the university students who played a decisive role in the social movements of the early 1990s, the SNC would presumably bring a solu- 
tion to the anachronism of the higher education system in Cameroon, the inadequate infrastructures of the university, the language barriers between Anglophone and Francophone students, the poor material conditions of the students, the growing unemployment rates among university graduates and the militarization of the university campus following the 26 May 1990 students' demonstration (Konings 2002:179-204). As one leader of the National Coordination of Cameroon Students, popularly known as Parlement put it:

A Sovereign National Conference is a forum for collective self-confession, a platform to point out our past mistakes and elaborate new codes of conduct; a process that will inevitably lead to a positive restructuring of our unadapted education system and its mediocre university, and that will eventually lay the foundation for the resolution of post-university problem such as unemployment. ${ }^{19}$

But if the call for the SNC gained a tremendous support from the grassroots or took a particular tone in this country, it was because many people considered the SNC a godsend that the discriminatory regime prevented them from enjoying. According to Mono Djana, one of the ideologues of the ruling CPDM, people were ready to die for the SNC, because the opposition leaders made illiterate peasants and poor urban populations believe that it was a big coffer full of money. President Paul Biya allegedly refused to open this case and inject the money it contained into the national economy which was cash-strapped at that time. Moreover, it was said that he kept the case closed to other people, while at the same time he generously opened it to his own Beti kinsmen, or let the money only flow towards his native region in the South Province of the country. This explains, according to Mono Djana (1997:24-26), why many people were determined to force Paul Biya, not only to release the coffer which held the 'magic money' but also to step down (see also Mono Djana 1999, 1992). The success of the SNC in other African countries like Benin (Nzouankeu 1993; Takougang and Krieger 1998) comforted people in their faith that 'want it or not, the Sovereign $\mathrm{Na}$ tional Conference must be held' (faire quoi, faire quoi Conférence Nationale Souveraine, il y aura) or that 'Biya must go'.

Undoubtedly, the charismatic leader of the SDF, Ni John Fru Ndi, was the leading figure of the 'Front of Allies for Change.' The aura, courage and popularity of the man positioned his party at the top of the opposition movement in the country. Never before had a local politician been as glorified as the leader of the SDF was at his heyday. Between 
1991 and 1996, he was so popular with both the rural populations and the underprivileged of the urban areas that his fame sometimes took a form of idolatry or a religious cult. In a number of houses, private offices or squares, the portraits and pictures of the man whose sympathizers affectionately called 'Chairman' had replaced those of the Head of State.

In July 1992 when I travelled to my village a few months before the controversial presidential election of October of the same year, I was really amazed to discover that most villagers were wearing clothes with Fru Ndi's images or were considered SDF supporters. Even my old grandmother had the man's icon at the head of her bed. For her, as with other people I talked to, Ni John Fru Ndi was more than a simple political leader whose supporters were attracted by his political program or discourse. He was above all a national hero who united many Cameroonians against their common enemy: the Biya regime. Many people referred to his party (SDF) as a salvation political party that would put an end to people's distress and suffering. As one of my relatives who was a faithful SDF militant explained to me,

When Ni John Fru Ndi will unseat Paul Biya and achieve the changement, people no longer pay tax, electricity bills, and other charges that go into the pockets of the thiefman from Yaounde (he referred to the Head of State who lives in Yaounde). The price of cocoa and coffee will be increased. You too will enjoy the changement, because when you finish your studies, you will find a good job and earn lots of money. Everybody will be happy, not like the present day where you go to school, but you cannot get a job when you graduate. And even when you do find some, you work but they don't pay you.

Other people considered Ni John Fru Ndi a redeemer-prophet who was entrusted with the messianic mission to lead his people to the eagerly awaited SNC, which was seen by many as the ultimate achievement of the political struggle in the country. More importantly, if the man was able to magnetize the public, it was because many people perceived him as the only powerful fetish which could help them fulfil their main aspiration: remove the ghostly Paul Biya who was held responsible for people's misfortune and suffering from power. No wonder that in the regions favourable to the opposition movement or which were in the frontline of the ghost town operation, Ni John Fru Ndi received almost a plebiscite during the aforementioned controversial presidential election of October $1992 .{ }^{20}$ In the following pages, I want to examine the two dominant modes of rationality employed by the Biya regime, not only to corrupt 
the democratization process in this country, but also to strangle or suppress the opposition movement, at least to render it less effective. These two modes of governmentality took respectively the euphemistic and formal appellation of 'advanced democracy' (démocratie avancée) and later 'appeased or pacified democracy' (démocratie apaisée).

\section{Démocratie avancée: The Birth of the Tragedy}

First of all, it is useful to emphasize that the political reform of the early 1990s that is improperly called a democratization process did not really affect the legal or judicial structure of the former authoritarian system, ${ }^{21}$ nor did it have a positive impact on the political public sphere. In many respects, it seemed rather to marshal the project to reinforce the state's authority or to extend its scope of domination and control over the citizens and the political landscape. As I have shown in a previous article (Ndjio 2005:265-94), the democratization process in Cameroon did not lead to the constitution of a democratic and liberal public sphere which guaranteed freedom of assembly and association, and the rights of citizens to freely express and publicize their opinion about matters of general interest, etc. ${ }^{22}$ Instead, it had given way in this country to the establishment of a 'manipulated public sphere,' not in the sense Habermas (1989) understands it, but rather as a politically structured space which was permanently overloaded with signs and symbols that articulated the state authority or represented its power, as well as dramatized its importance. One can recall in this respect the presidential thoughts and declarations of principles printed on notice boards or written on the facade of main state buildings, or his speeches which were constantly and repeatedly echoed or commented by the state-controlled media.

If the introduction of multi-party politics in 1990 changed anything in this country, it was the perversion of the political liberalization by the ruling CPDM regime, or at least its transformation into what came to be institutionalized from 1991 onwards as 'advanced democracy'. This tropical democracy which had negatively affected the lives of many Cameroonians meant recourse to violence, intimidation and manoeuvres in order to muzzle or ostracize the opposition, notably members of the hardcore opposition mentioned earlier. At the time of the 'advanced democracy', opposition was only tolerated if its members were 'moderate' or 'responsible,' and did not advocate the dismissal of the 'Father of the Nation,' the holding of the SNC or the organization of fair and democratic elections in the country. The Biya regime also put up with a 
'responsible opposition' or a 'civilised civic society', which did not denounce the kleptomaniac behaviour of the politico-bureaucratic elites. Along the same lines, for this regime, the conscientious and responsible political opponents were what people derisively called the 'oppositionists to the opposition' (opposants de l'opposition); that is, political opponents who were 'willing to have talks with the government and constituted authorities,' or were opposed to members of the hardcore opposition coalition who formed the 'Front Allies for Change'. ${ }^{23}$ This was the case for members of the opposition group known as the 'moderates' (modérés) whose collusion with the ruling CPDM was generally praised by state officials and pro-government media as a sign of responsibility and patriotism. It was also the case for members of the so-called 'civil society' who were 'neutrally' connected to the ruling CPDM party, or members of many figurative human rights associations hastily created by the government in order to mislead the international community.

This new mode of governmentality implied as well the conversion of the public space into a militarized and martial space in which order and peace had to be maintained by all means (militocracy). At the time of the advanced democracy, the state power strove, not only to recapture the public sphere that was once controlled by young 'freedom fighters' and 'revolutionaries' but also to dramatize its presence where its authority was less perceptible. One could mention in this respect the formation in July 1991 of a special armed force unit baptized Commandement Opérationnel in regions mostly favourable to the opposition movement, the creation of new administrative units, military legions, the increase of the number of armed forces, administrators and magistrates, the constitution of ethnic militias and vigilante groups, and above all the retour en force of some caciques of the conservative ruling CPDM regime. This was the case of Gilbert Andzé Tchoungui, the former Minister of Territorial Administration and patron of the police, who was appointed as Deputy-Prime Minister in charge of the Territorial Administration, and Jean Fochivé, the dreaded former boss of the intelligence service, who became Secretary of State for Internal Security. The promotion of these two hardliners fit into the government's scheme of 'restoring the state power', as the official rhetoric called the violence that the postcolonial state permanently exercised on its subjects. These different measures were above all part of the government's effort to create submissive and docile citizens who had to subjugate their rights to the state authority. At that time of the advanced democracy, sympathizers of the opposition 
only experienced the state power in its cruellest and most cynical visage. For these men and women who were constantly chased, arrested, tortured, or at the very worst killed by security forces or ethnic militias, because of their political conviction or ethnic origins- , the experience of life was intrinsically linked to the art of escaping death and tragedy everyday. ${ }^{24}$ Yet, even in its ferocity and intemperance, power was never banal or trivial in this country. The permanent assaults that this authoritarian power exerted on the oppositionists' bodies were always meant to remind them that the state authority has 'the will and the means', as $\mathrm{Mr}$ Fochivé liked to say.

One imposing aspect of this advanced democracy was that it had oversimplified the procedures of authority, and the means of violence and coercion in this country. In deed, from 1991 to 1996, the daily exercise of (state) power in Cameroon was abridged to the elementary act of banning, constraint, force, prohibition, confinement, surveillance and punishment, but also authorization, permission, rewarding, etc. Any person, thought, action or movement that was likely to challenge the gospel truth professed by His Excellency and his honourable Ministers was ostracized. For example, 1991 and 1992 witnessed the detention of many activist leaders who were subjected after their arrest to a humiliating and savage treatment by security forces. The same period also heralded the interdiction of a great number of independent newspapers which were very critical about the Biya regime ${ }^{25}$ or many independent human rights organizations, such as CAP-Liberté, OCDH, Human Watch, True Democracy which played a decisive role in increasing national and international awareness about the abuse of human rights in Cameroon. These associations were suspected by the administration of being connected to the main opposition parties (SDF, UNDP, UPC), and especially of being manipulated by the Laka'am association, a powerful Bamiléké lobby-group which was reputed for its strong hostility to the CPDM government. This period also recorded the dismantlement of all student movements, most notably the popular Parlement (an active and radical student movement) whose leaders were expelled from all state universities, jailed or tracked down by security services and ethnic militias in the government's pay (Collectif Changer le Cameroun 1992). At the same time, the officials managed to create or promote some amenable organizations, or some private newspapers, such as Le Patriote, La Caravane, Le Témoin, Le Devoir, Elimbi, etc, which enabled them to maintain a democracy de facade. 
Yet this mode of exercising power entailed above all a policy of stickand-carrot towards the government's opponents. On the one hand, this policy referred to an ineradicable custom of bringing members of the radical opposition, who were contemptuously depicted by pro-CPDM barons as a 'bunch of vandals and rioting demonstrators', under the endless process of pacification. In many respects, this art of discipline and castigation of the political opponents took the form of a real hunt in which the forces of law and order were the hunters and opposition supporters the quarry. As a matter of fact, from 1991 to 1996 the main task of the security forces consisted in hunting, tracking down, trapping and taming Biya's political opponents, in the same way that a hunter deals with its prey. And each time the gendarmes or police 'captured' the oppositionists, they took a cynical delight in exhibiting them on the statecontrolled television as a spoil of war, or humiliating them in public, so as to remind them that 'L'Homme-lion is stronger than them,' or to make them become less 'irresponsible and stubborn'. Sometimes, they required their victims to sing the praises of 'the Man of the New Deal' (L'Homme $d u$ Renouveau), as the despot is affectionately called.

However, not all these structures of repression or hunting (police, gendarmes, army, magistrates, etc.) had a legal or official status. Some of them were informal, private or extra-judiciary. This was the case of the Committee for Self-Defence, Commando Delta, Direct Action, the National Front for Beti Liberation and Essingan Group, the five most notorious and extremist Beti militias created in the early 1990s by some Beti officials, and the Presby group (President Biya's youth organization), a fanatic organization closely connected to the ruling CPDM party. Most of these groups were formed along ethnic or regional lines. More precisely, they recruited their members exclusively among young Beti students or unemployed to whom fine promises (government's assistance, job opportunities in the administration or the army, etc) were made in order to win their support. Between 1991 and 1996, these associations played a crucial role in helping the government to implement its martial policy against the opposition movement, notably members of the students' Parlement organization. For example, on several occasions, the government authority had recourse to these ethnic militias to achieve various tasks, i.e. maintaining or restoring order in the university campuses, disturbing opposition rallies or demonstrations, but also repressing young pro-democracy activists who were at the forefront of 'the ghost town operation' in the main towns of the country. Most of the victims of 
these ethnic militias who were defined as 'the New Deal's defenders' (défenseurs du Renouveau) were populations from other regions or ethnic groups which were singled out as 'enemies' of the New Deal' or as 'strangers' (allogènes) in opposition to the so-called Beti 'natives' (autochthones).

Nonetheless, we will miss another important dimension of this advanced democracy policy, if we only limit it to a regime of disciplinary power or a routinized use of violence and coercion which was just one aspect of the whole complex of what Michel Foucault (1991) has called 'bio-power.' As he has cogently demonstrated in Discipline and Punish (1979), for power to work, it must be able to manage, to control, and even create details: the more detail, real power, management breeding, and management units, which in turn breeds more detailed and finely controlling knowledge. From this Foucauldian perspective, one can read the advanced democracy policy as an elaborate system of representations of the Other (opposition members) and a sophisticated construction of ideological knowledge that enabled between 1991 and 1996 the CPDM regime to legitimize the violence and humiliation it constantly inflicted on its political opponents. I will focus my analysis on two main discursive formations that underpinned this mode of governing people in the country known as Cameroon.

The first discourse that aimed above all at manipulating the collective consciousness was associated with the mythology of national unity: a federal term on which Cameroonians generally agree, regardless of their ethnic, political or religious affiliations (Sindjoun 1996:27-51). As developed above, unlike the opposition movement which perceived the multi-party politics as hopeful because it embodied the project of 'change', the ruling CPDM regime rather viewed the democratization process as threatening for its maintenance in power. Therefore, throughout 1991, confronted with unprecedented social and political unrest, the CPDM government strove through images, pictures, sounds and statements to systematize a coherent discourse that emphasized the need to preserve what supposedly brought Cameroonians together: the 'national unity' and their pride of belonging to 'one and indivisible country.' Eventually this mythology became the repository of official discourses on peace, public order and security. In all respects, the (re) invention of this mythology of national unity, which since 1960 has been providing ideological support for the institutionalization of an autocratic regime in this country (Alima 1977; Kegne Pokam 1986), went hand in hand with the government's project, not only to supersede the ideal of 'change' by the 
logics of peace, but also to alter the ongoing democratization process. Not surprising that, during the presidential election of October 1992, one of the main slogans of the ruling CPDM party was 'Vote Paul Biya for Peace' or 'Paul Biya for peace.' On the other hand, the outgoing President Paul Biya passed himself off as 'the candidate for gathering and unity' (candidat du rassemblement et de l'unité), in contrast to his political opponents who were dubbed 'apostles of division and enemies to peace' (apôtres de la division et ennemis de la paix). Cameroonians were called upon to make their choice, not between 'change' (changement) and 'opposition to change' (immobilisme), as the opposition members stressed, but rather between unity and division, order and disorder, peace and chaos, stability and instability, etc, as the state-controlled media endlessly reminded the public.

In the wake of the brainwashing campaigns initiated by state officials in order to discredit the opposition movement or to hamper the impact of the devastating civil disobedience, special programs were regularly broadcast on the national TV or radio channels on civil wars that were devastating some African countries. In most cases, these shows were accompanied by dithyrambic songs that either paid tribute to the 'Initiator of the New Deal policy,' or urged Cameroonians to 'give priority to peace and stability, whatever their political disagreement.' Furthermore, government officials appealed to some actors of the reunification of the two former French and British Cameroons, not only to explain how Cameroonians from the two borders of the Moungo river decided after the Reunification of October 1961 to live in common but also to warn those 'irresponsible fellows whose actions were likely to jeopardize the national unity gained at great cost.' No wonder that the mythology of national unity became one of the main justifications for the militarization of the power that marked the debut of the advanced democracy of the early 1990s, or the systematization of the policy of 'pacifying' and 'stabilizing' the country by all means.

Indeed, it was for the sake of national unity and peace that unlimited rights were given to the forces of law and order to bring the oppositionists' bodies under the endless process of discipline, or that the Biya regime reinforced its repressive tendencies that have contributed to its hegemonic stability (Courade and Sindjoun 1996). It was under the pretext of preservation of national unity and territorial integrity that the CPDM government was strongly opposed to the holding of SNC or dismissed the claims of some Anglophone populations for the reintroduction of a fed- 
eral system (Anglophone and Francophone States) or the outright secession of the former Southern Cameroon from the present Republic of Cameroon. Instead, the Constitution of January 1996 preferred a formative decentralization system that espoused the form of the ten existing provinces to federalism, viewed by the regime ideologues as a step to secession (Awasom 2001).

Another aspect of the 'advanced democracy' is that it embodied the dichotomizing representation of Cameroonians or their classification into two categories: supporters and opponents, good and bad citizens, responsible and irresponsible subjects, patriots and the non-patriots, autochthons and allochthons, allies and enemies, natives and strangers, etc (Awasom 1999; Konings 2001:169-94; Socpa 2002). This classificatory policy primarily aimed at exacerbating regional, ethnic, cultural and linguistic differences. In practice, this process gave way for instance to the invention of the Beti or Essigan clan that encompassed populations of the forest region of Cameroon (Centre, Southern and Eastern Provinces), the Sawa group that gathered peoples from the coastal region (Littoral and South-western provinces), the Anglo-Bami group that assembled populations from the Grassfields region (West and Northwest Provinces), and finally the Nordistes that grouped peoples from the Northern region of the country. Beti and Sawa populations were generally associated with the ruling CPDM party, while the Anglo-Bamileke and the Nordistes were connected with the opposition, notably SDF and UNPD (Union National for Democracy and Progress ). At the time of the advanced democracy, the political status, privileges and rights one could enjoy or not, depended above all on one's position either as a CPDM supporter or opponent, as a member of Pays Organisateur (the Beti lobby group which allegedly holds the political power in Cameroon) or Anglo-Bami, or as an 'autochthon' or 'allochthon.' Reflecting on this policy, one can say that what some analysts have rightly termed 'ethnopolitics' or 'autochthony governmentality' (Geschiere and Nyamnjoh 2000:423-52) can be seen above all as the art of (re) inventing difference. As a matter of fact, political opposition was equated with regional and ethnic differences: the opposant was the allogène or the 'alien,' while the supporter of the ruling CPDM party was the autochtone or the "son of the soil,' who needed to be protected against the invasion and cumbersome presence of the allochthons from the Grassfields region (Awasom 2001; Socpa 2002). 
For example, between 1991 and 1996, the Biya regime enacted a series of laws, which were purportedly and ostensibly designed to protect the 'autochthons' and the 'natives' who allegedly feared of being overwhelming or outvoting by Anglo-Bami 'settlers' or 'came no gos,' in their native region (see Geschiere and Nyamnjoh 2000:434-45). This was the case with the Electoral Code of 1992 and the January 1996 Constitution which not only institutionalized the ethno-politics in this country but also endorsed the CPDM regime's divide-and-rule policy, which was based above all on the exclusion or marginalization of a crosssection of populations. For example, the Electoral Code required that the list of candidates to be presented by political parties in a constituency must reflect the sociological components of this constituency. This means the mandatory inclusion of 'autochthon' populations or the 'sons of the soil' in the list of candidates presented by a political party. In the same lines, in its preamble and in Article 57(3), the Constitution of January 1996 upheld the state's obligation to 'protect minorities and preserve the rights of indigenous populations.' Moreover, this law stated that 'the Chairperson of each Regional Council and Local Government region shall be an indigene of the area.' As Awasom (2001:22) rightly puts it, 'the emphasis of the 1996 Constitution was on the rights of 'indigenes' and 'minorities' against other nationals considered 'outsiders' and 'strangers." To phrase it differently, priority was given to 'ethnic,' 'indigenous' or 'autochthonous' citizens, while the concept of national citizenship was relegated to the background. This constitution, as Awasom (2001:23-4) further explains, 'stratified citizenship by starting first with belonging to an ethnic group, district or province before any national consideration.'

What deserves to be stressed here is that these different laws have been instrumental in the conservative CPDM regime's bid not only to distort the democratic principles, but also to maintain its hegemonic stability, by impeding through 'legal' means individuals or groups who were likely to pose a threat to its conservation of power. For example between 1992 and 1996, the CPDM government had many times recourse to these judiciary and electioneering procedures to prevent 'AngloBamis' and Nordistes strangers from standing for election in the regions where they were born or had lived for several decades, because their status allegedly did not comply with the policy of belonging. On several occasions, the CPDM regime used similar stratagems either to disqualify the list of the opposition candidates from the electoral competition, or 
to invalidate the opposition's victory under the pretext that it was predominantly made up of 'allogènes' at the expense of the 'autochthons.' For example, prior to the January 1996 municipal elections, the Minister of Territorial Administration disqualified the list of SDF candidates in 150 local government constituencies on the grounds that it did not reflect the sociological components of the respective areas, or that the 'natives' were less represented in those lists than the 'aliens'. ${ }^{26}$

Under the advanced democracy, the invention of ethnic and cultural differences also took the form of demonization, anathemization and pathologization of the ruling party's opponents, notably members of the radical opposition reunited under the banner of the SDF. Indeed, militants or leaders of this party were generally considered a bunch of "vandals' and 'irresponsible fellows' who deserved no respect on the part of the state officials. For example, Mr Kontchou Kouemegni, the former Minister of Communication (1990-2000) had once called this political movement a 'fascist party,' which was indoctrinating young Cameroonians, and had planned to plunge the country into chaos and tragedy. Twice, Ni John Fru Ndi, the chairman of this party escaped a murder attempt by the security forces who shot at his car and wounded the man and one of his bodyguards. In the line of such a policy, CPDM regime's political opponents and members of some radical Anglophone movements, such as the South Cameroon National Council (SCNC), Free West Cameroon Movement (FWCM) or Ambazonia Movement, which advocated the return to the former federated states, were depicted as 'adventurers', 'traitors in the enemy's pay', 'power-mongers', 'enemies to peace,' 'trouble-makers,' 'apostles of division,' 'secessionists' or 'undesirable elements' (Konings and Nyamnjoh 2003, 2000:5-32). Likewise, extremist members of the ruling CPDM and pro-governmental newspapers generally referred to 'Anglo-Bami' populations as 'ethnofascists,' 'black imperialists,' 'exploitative and unscrupulous fellows,' 'domineering settlers,' 'land-grabbers,' 'ingrate peoples,' 'deceitful peoples,' etc. They were accused of sowing disorder in the country, or of plotting to overthrow the CPDM regime by means of 'ghost town operation' and SNC, as Mono Djana (1997:23-25) stated. In the following pages, I will focus my analysis on the second mode of governmentality that has enabled Biya regime to cannibalize the pretty siren of democracy, or to 'capture' its political opponents, who have been turned into mere ceremonial figures. This new formula of domination took by the end of 1997 the official appellation of 'pacified democracy' (démocratie apaisée). ${ }^{27}$ 


\section{Démocratie apaisée: The End of the Political Struggle}

In December 2001, I had the opportunity to dine in a smart restaurant in Paris with a group of Cameroonian mayors from the CPDM and SDF parties, who were participating in a meeting on local government in the French capital. Both the CPDM and SDF mayors, who had been put up at a luxurious hotel at the Place de Clichy, were calling each other 'colleagues' or 'comrades.' Some of them even planned together to ship the fancy cars that they had just bought into Cameroon. Their trip and daily expenses were supported by a government institution (FEICOM), which provides financial assistance to local councils. A couple of months earlier in July, Ni John Fru Ndi, the Chairman of the former radical SDF was the CPDM's special guest during the ruling party's $2^{\text {nd }}$ extraordinary congress. For many participants and viewers, it was memorable to see the man who was formerly cast in the role of the villain, seating alongside the Prime Minister and members of his cabinet, or holding a friendly conversation with the ruling party's Secretary General. It was the same CPDM regime that in 1997 and 2002 helped the SDF Chairman to thwart his former collaborators' plan to unseat him for 'high treason and collusion with the 'enemy' (meaning the CPDM party) ${ }^{28}$

Paul Biya's unexpected support for his former 'enemy' was above all a politically motivated action. On the one hand, his intervention in favour of the leader of the so-called radical opposition party enabled his regime to keep up its 'cosmetic democracy' to use Njamnjoh's words (2004), since without an 'active and responsible opposition,' as statecontrolled media often say, the democracy made in Cameroon would not catch fire. On the other hand, Paul Biya's backing of an Anglophone fellow that his regime has been promoting since 1996 as the everlasting leader of the opposition in the country was part of his strategy to maintain an illusionary equilibrium of power between a dominatedFrancophone government and a pro-Anglophone opposition. This fragile balance might have been undermined, if a Francophone Bamileke or Nordiste fellow who was lusting after the chairmanship of the main opposition party in the country, had replaced the old Anglophone leader. Moreover, ousting Ni John Fru Ndi would have compounded the Anglophones' resentment against their Francophone counterparts they often accused of marginalizing them (Konings and Nyamnjoh 1997:20729). As one analyst commented, 'for the Biya regime, it was a matter of choosing the lesser of two evils: between the long-time opposant whose 
bark was worse than his bite, and especially was willing to negotiate with the ruling CPDM regime, and embittered politicians who had a score to settle with the same regime' ${ }^{29}$

In many respects, the government's surprising support for the leader of the former radical party tied in with its policy of 'appeasement' which embodied the Second Coming of the democratization process in this country: that of the 'advanced democracy'. This 'pacified democracy' moved the political struggle in this postcolonial state from the former logics of confrontation and opposition of the early 1990s to that of collaboration and connivance. The 'ghost town operation' was over, the $\mathrm{SNC}$ was postponed indefinitely, the former radical opposition had become 'responsible,' and order and peace were restored at the expense of the former 'freedom fighters' and 'combatants.' To paraphrase Bayart (1993), the policy of appeasement initiated by the CPDM government in the late 1997 dramatized the logics of reciprocity and mutuality that now inscribes both the ruling party and its opposition within the same episteme of belly euphemistically called government of 'large consensus' or 'national reconciliation.' Like a good father, the 'Enlightened Guide' in his paternalist magnanimity, refused to banish or ostracize anyone, not even the 'lost sons' who had once dishonoured him or slammed the door of the communal house behind them. As Zacharie Ngniman (1998:12), one of the apologists of the CPDM regime, explains,

On the 12 October 1997, Paul Biya was re-elected as President following his large victory (92.57 per cent of recorded votes) during the presidential election. For many observers, there was no doubt that, unlike the 1992 presidential election during which he only cast 39. 97 per cent of the votes, this time, he had elbowroom to govern with his CPDM party alone. All the more reason that at that time, he already enjoyed a comfortable majority at the National Assembly (the Cameroonian Parliament). But he did not. In his inaugural speech, President Paul Biya rather chose to associate all political trends to his power. In addition to the ruling CPDM, other political parties joined the government (UPC, UNDP, UPR). Official talks began with the SDF, the long-standing rival, with more or less success. Despite the divergence of opinion and some minor clashes, the trend was irreversible. The new option signalled the end of the democratic transition and the beginning of the 'démocratie apaisée' in Cameroon. On the eve of the $3^{\text {rd }}$ Millennium, and with regard to what we witnessed in the neighbouring countries, the President's policy of appeasement was an advantage that one had to preserve jealously (translation by the author). 
As the above quotation shows, the 'pacified democracy' embodied the shift, not only in the style of power and the CPDM regime's mode of governance but also in the way in which it dealt with its opposition. Unlike the advanced democracy of the early 1990s which was predominately marked by the policy of stick, the pacified democracy of the late 1990s was rather guided by the policy of carrot towards opposition members. It means that, if in the past years (1991-1996) boot, truncheon, tear gas, bayonet, bullets, beatings and imprisonments were the privileged means for keeping the opposition movement in check, after October 1997 incorporation in the state apparatuses, money and reward became the principal instrument for domesticating the opposition. Even though this corruptive practice was not really new, as in March 1992 the CPDM government resorted to bribe to break up the former Coordination (a coalition of 40 opposition parties),$^{30}$ it had never been as conventional and prevalent as it became under the pacified democracy. In other respects, the spirit of appeasement changed even the official representation of the hardcore opposition: its leaders were no longer considered 'troublemakers,' 'apostles of division,' 'enemies to peace,' but were called 'our friends of the opposition,' 'challengers' (concurrents), 'political adversaries,' etc. Take, for example, Ni John Fru Ndi who was formerly called all the names under the sun by state-controlled media. With the advent of the pacified democracy, he became in the same official media's representation the 'leader of the opposition' or the 'Chairman of the SDF.' Moreover, he was now invited to join state or ruling CPDM officials in their display of majesty and grandeur, while his party's militants were now allowed to hold their meeting or to march past the Head of State during the National Day celebration.

However, one of the main achievements of this pacified democracy is that it has established an entente cordiale or a whirlwind romance between the former 'enemies' who have (re) discovered 'the virtues of dialogue and consultation,' as Mr Achidi Achu, the former Prime Minister (19921996), liked to say. Moreover, it has contributed to a fusion between the ruling CPDM and its opposition, or their 'reciprocal assimilation's1 in the matrix of what some Cameroonian officials have felicitously called 'mutual aid policy' ('njangui politics')' ${ }^{32}$ It means that both the government and the opposition no longer view themselves as adversaries or political opponents, but rather as partners or allies who are trying to make the most of the accumulative opportunities provided by the millennial democracy. In practice, this alliance operates in the form of 
share of the 'national cake,' or what Bayart (1993:155-179) has called 'the resources of extraversion:' for the greater good of the country, and for the sake of national unity and peace, the opposition allows the ruling CPDM party to rig the elections or to distort their results. In turn, for the sake of national reconciliation and appeasement, its leaders are showered with money and other gratifications, or are allotted a less important position in the government or in the executive board of the National Assembly, while some of them are appointed to some lucrative posts in one of the state-owned companies (Mbuagbo 2002:431-38; Mbuagbo and Akoko 2004:1-12).

Indeed, since 1997, both the Parliament and the government have been serving as spaces, not only for mediation between the ruling CPDM regime and its opposition but also for reconciliation between political actors who were formerly divided by the advanced democracy. It is useful to recall that since the implementation of the pacified democracy in October 1997, both the CPDM and the SDF have been controlling the government body of the National Assembly: the National Bureau and the Commissions. For example, to compensate for the absence of its main challenger in 'the government of national union,' the ruling party has promoted the 'election' of some SDF's Members of Parliament as Deputy-Chairman, Secretary or Treasurer of the Parliament, or as Secretary of one of the nine Commissions. As the official leader of the opposition, the SDF Chairman receives the state allowances (Mutations, 27 September 2004). As Tenfack Ofegé, a Cameroonian journalist cogently writes,

Under the pretext that they are the guarantors of peace and stability in Cameroon the CPDM operates a kleptocracy wherein 10\% of the population or less controls $90 \%$ of the resources. And under the pretext that they are not part of the CPDM racket, but they are the guarantors of a democracy, the current SDF leadership sponsors a system wherein $10 \%$ of the party's leadership, not even the masses, benefits from the graft with the CPDM. ${ }^{33}$

No wonder that the former whining opposants have fallen silent. To Thomas Frank's pertinent question, 'Why Johnny can't dissent'? ${ }^{34}$ No doubt the answer of many disenchanted Cameroonians would be because "the full mouth is silent' (la bouche qui parle ne mange pas), as 'the talkative mouth is empty' (bouche qui parle ne mange pas).

In many respects, the njangui politics that is one of the main characteristics of the pacified democracy seems to take the form of a democ- 
racy of the belly (démocratie du ventre) and a corruptive democracy, if one acknowledges the present propensity of opposition leaders to lust after ministerial posts, and the inclination of the ruling party to bribe its political opponents in order to calm them down. Indeed, with the newly institutionalized pacified democracy, a new practice of politics has emerged in Cameroon in which making politics is abridged to the art of fending for oneself, or of 'eating one's portion' (manger sa part), as the man in the street ironically comments. Unlike the early 1990s when the political struggle was essentially driven by the mythology of change, and when making politics was above all a matter of changing the existing political order or reframing the postcolonial state, that of the late $1990 \mathrm{~s}$ was primary prompted by the "need to acquire the patrimonial means of one's political legitimacy,' as Chabal and Daloz (1999:37) would have put it, or to share the spoils. Reflecting on the vegetative and primal behaviour of many of them, one can rightly say that nowadays, Cameroonian political actors are not far from what Bayart (1993:243) felicitously describes as 'glutinous enzymes motivated by the sole desire of stuffing themselves as quickly as possible with the fruits of western modernism' or with international aid.

Even the vivid popular culture in Cameroon reflects this rush for spoils in which almost all local political entrepreneurs participate today. For example, in one of his successful sketches that is in fact a political satire about the democratization process in Cameroon, the popular comedian Chop-Chop derisively describes the ongoing pacified democracy as the 'democracy for personal interests' (démocratie du gombo ) or 'mangecratie:' the democracy for the mouth and the belly, as he explains. According to him, the government and its opposition are engaged in what he calls the 'chop-chop démocratie.' That is why he too has created a party, which is named 'Chop-Chop Democratic Party,' and his militants are called 'chopchop people'. The party's motto is: 'I chop, you chop' (I eat, you eat). The main objective of the party's leader is to get some "money or financial retributions' (chops or gombos) from the CPDM government or international donors. In many respects, his manoeuvre consists of ranting at the government in order to draw its attention. His overt opposition to the ruling CPDM power is only a hidden transcript of his collusion with the same regime. More explicitly, in public, the cunning politician passes himself off as a radical opposant who regularly criticizes the CPDM regime for keeping people in poverty and destitution. But in private, he lives off the same government that offers him opportunities to tap into 
state-controlled resources permitting him to enjoy an easy life. The strategy of the leader of the Chop-Chop Democratic Party is informed by the fact that the prevailing pacified democracy works because there are (responsible) political opponents who legitimize it through 'elections,' votes of laws in the National Assembly, or through formal institutions (Parliament, government, local council) or through actions such as critiques, demonstrations, marches, etc. He is also aware of the fact that under the pacified democracy, to get access to the state resources, you have to play-act as a vehement political opponent: a turbulent opposant who shouts angrily at the government or casts aspersions on the ruling CDPM regime, is likely to be called to the government, ironically translated by Cameroonians as a 'big dish' (mangeoire nationale).

One can find here a striking similarity between the Chairman of the Chop-Chop Democratic Party and many 'ventriloquist political opponents' (opposants du ventre), as the popular literature in Cameroon calls it. Their political struggle is no longer subjected to a double logic of 'totalitarianizing and de-totalitarianizing' (Bayart 1993:249), but rather to a double process of collaboration and integration, as exemplified by the note released on 27 October 2002 by the Chairman of the SDF. In this message, the leader of this opposition party 'directs the Secretary General of the party to send an official letter to the Secretary General of the CPDM to invite his party to another round of CPDM/SDF talks, like the one they initiated in 1997/98'. ${ }^{35}$ The declared purpose of these talks engaged in since November 1997 was 'to seek avenues to perfect the electoral system in Cameroon,' as stated by the aforementioned message. But their hidden objective aspired to consolidate the place of the former radical party in the banquet of the pacified democracy which today offers to all the opposants $d u$ ventre a fresh field in which to graze: allocations of micro-projects, lucrative public contracts, highly marketable import-export licenses, etc.

\section{Conclusion: From Millennial to Spectral Democracy}

In the early 1990s, Cameroonians, like many Africans, fantasized about a democracy that supposedly would bring about a real change in their country, which would at least prevent their old Enlightened Guide from dying in power. Indeed, the millennial democracy in its messianic and enchanting manifestations promised to put an end to the tragedy and suffering Cameroonians in particular, and Africans at large, have been experiencing since the so-called de-colonization process of the late 1950s 
and early 1960s. The (magical) word 'changement' embodied people's expectations of better life, justice and freedom. But in the end, the 'Father of the Nation' succeeded in turning the pretty siren of democracy into a kind of spectre which since 1991 has been traumatizing people, except the cunning politicians who have been able to make the most of the pacified democracy that has been preferred to democracy. The prevailing mangecracy and ethnocracy which have become the dominant manifestations of the Cameroonian governance bear witness to the failure of a democratization process that has changed everything in this country, except what it was supposed to change: corruption, nepotism, patrimonialism, favoritism, clientelism, tribalism, dictatorship, etc. Moreover, the steady process of autocraticization and criminalization of the Cameroonian state, like in many other African countries (Bayart et al. 1999), instead of democratization and good-governance as predicted by many analysts, is an unpleasant reminder that the modernist discourses have failed to understand the mutations that were taking place in Africa in the early 1990s. Once again, Africanists and social scientists at large have let themselves be led up the garden path by the mysterious Black continent and its people who seem to take a wicked delight in playing a trick on them, deconstructing their theoretical constructions, spoiling their project or shaking their certitudes and truths.

In the early 1990s, Ni John Fru Ndi and his SDF party were the incarnation of the millennial democracy. But today the former radical opposant turned nouveau riche has become the icon of the opportunist politicians who have sold the dreams of Cameroonians for change in favour of a system which today allows "kleptocrats and con men to live long and prosper,' as Sani Aladji, the former SDF coordinator for the Centre Province, points out. ${ }^{36}$ Both the fall of the man who formerly magnetized many Cameroonians, and the slowing down of the former 'people's party', as Cameroonians used to call it, bear today the historical consciousness of a general disenchantment with the mythology of change in this country. Many Cameroonians, who feel that con artist politicians have bamboozled them, translate today's democracy as demoncracy, for the former salvific democracy is now associated with tragedy, misfortune and distress, or with a horrible 'thing' (machin) that only exacerbates people's suffering, as many slum-dwellers of New Bell in Douala strongly believe. No wonder that the "calls on the Cameroonian people neither to resign themselves to their frustrations and anxieties, nor loose interests in politics, as this would be acceptance of Biya's mockery of Cameroon 
and its people,' like the one the SDF National Executive Committee made in October 2002, ${ }^{37}$ only leave people impassive. No surprising too that when, during the campaign for the presidential election of October 2004, Paul Biya (the then CPDM candidate and outgoing President) talks of his 'greater ambitions' (grandes ambitions) that will magically transform the 'kleptocratic and felonious' Regime du Renouveau (Bayart et al. 1999) into a democratic one, sceptic Cameroonians disdainfully considered them another 'greater illusion' (grandes illusions)'38 (Le Messager on line 13 February 2005).

\section{Notes}

I would like to express my thanks and gratitude to Sara Dorman and Edlyne Agnuwon for helping me to edit this text. I am also grateful to Peter Pels and the two anonymous reviewers for kindly reading and commenting on the first draft of this work. This paper was written during my academic affiliation with the Amsterdam School for Social Science Research of the University of Amsterdam, and reflects somehow the 'spirit' and vitality of the extraordinary group of scholars and postgraduate students to whom I am intellectually indebted.

1. Messager, no 1785, 14 November 2003:4.

2. He finally died in power on 5 February 2005, following a heart attack.

3. See Toulabor 1991:55-71.

4. Their political engagement which entails, to a certain extent, their political consciousness.

5. See Mutations, 12 March 1999:5.

6. This developmentalist and modernist ideology can be found in the writings of some leading figures in political sciences such as Azarya 1994; Azarya and Chazan 1987; Bratton 1989; Bayart 1986; Haberson, Rothchild and Chazan 1994; and Fatton Jr. 1987. For a critical analysis of this western liberal policy, see Badie 1992; Comaroff and Comaroff 1999; Frank 1991; Hibou 1998; and Touraine 1992.

7. See Ferguson 1999.

8. By demo-cracy, I mean a legitimate or legal form of domination that politicoadministrative elites or those who have control over state resources and international funds exert over subaltern groups. In short, this concept refers to a form of power on people.

9. See Hibou 1999.

10. In many African countries, National Conference, Roundtable or National Debate offered a framework for mediations between various political actors. See Eboussi Boulaga 1993; Nzouankeu 1993; Clark 1998.

11. See his interview with the French journalist Yves Mourousi in February 1990. See also Mono Djana 1992. 
12. See Cameroon Tribune, 5 December 1990:3.

13. This will be discussed in detail in the next section.

14. Following the refusal of the ruling party and its president to concede the organization of the sovereign national conference. On 21 March 1991, the Political Bureau of this party issued a communiqué in which it expressed its strong opposition to the sovereign national conference that was declared sans object (groundless). On 27 July 1991, Paul Biya reiterated his refusal. Moreover, he created a special armed force unit baptised Commandement Opérationnel. See Sindjoun and Owona 1997:218-19.

15. In L'Express, 8 March 2004

16. See Konings 2002:179-204.

17. Even the conservative ruling CPDM regime was not indifferent to this idea of 'change' for its leader claimed paternity for the introduction of 'change' into the country. As Paul Biya declared in a provocative speech he delivered on 27 June 1991 at the National Assembly: 'Do you want to change he who brought change into the country? I maintain that the national conference is pointless in Cameroon. Order will be maintained by all means'. Cf. Cameroon Tribune, 4916, 1991:2-3.

18. Cf. Challenge-Hebdo, 37, 1991:4.

19. In The Messenger, 18 April 1991:4 (quoted by Konings 2002:187).

20. During these elections which were marked by massive frauds organized by the incumbent regime, the candidate of the Union for Change, Ni John Fru Ndi, obtained respectively $86 \%$ in the Northwest, $52 \%$ in the South-west, $68 \%$ in the West and $68 \%$ in the Littoral Provinces, while his main challenger, the outgoing president (Paul Biya) only scored 8\%, 21\%, 12\% and $14 \%$ in these regions.

21. It is useful to underline that the new 'democratic laws' continue to cope with legal systems and institutions inherited from the former authoritarian system or copied from former colonial powers. These institutions remain under the authority or superintendency of the Head of State. For example, the amended 1996 Constitution has endorsed the control of the executive power over the so-called 'judicial power' by which members are appointed, transferred, dismissed, suspended by the administration.

22. For example, the alleged 'revolutionary' Mass Communication Law of November 1990 continues to restrict the freedom of expression through administrative and judicial controls over newspapers or to impose censorship through various procedures. See Nyamnjoh 1998:29-35.

23. See Cameroon Post, 27 June 1991.

24. For example, between April and November 1991 more than 500 protesters were shot dead by the security forces, while more than 3000 were arrested or detained without any trial. See La Messagère, 12 August 1991.

25. This was the case of Le Messager, La Nouvelle Expression, La Vision, ChallengeHebdo, Cameroon Today, Cameroon Post, etc., which were generally accused by Cameroonian officials of spreading false information, incitement to violence and hatred and outrage to the Head of State. 
26. See The Herald, 4 January 1996; L' Expression, 23 January 1996.

27. I thank Peter Pels for suggesting this translation, even if for the CPDM's ideologues, the démocratie apaisée indicates above all that Cameroon has moved from the former democracy of riot and violence of the period of 'ghost town operation' and civil disobedience to a 'peaceful democracy' (Ngniman 1998:12).

28. See Mutations, 28 September 2004.

29. See the article of Jean-Baptiste Sipa in Le Messager, 19 October 2002.

30. See Takougang and Krieger 1998.

31. On the fusion and reciprocal assimilation of the political elites, see Bayart 1993:150-179.

32. Receiving in 1994 a delegation of traditional leaders from his native region (Northwest Province), who came to express their grievances to him, Simon Achidi Achu, the then Prime Minister of Cameroon told them that they had to support the CPDM regime, should they want the state resources to flow towards their regions or villages. As he put it: 'politics na njangui' (politics is a mutual aid); you watch my back I watch your own.' Three years later, his successor, Peter Mafany Musonge repeated the same principle to his village fellows (Southwest Province) who came to congratulate him, following his appointment as Prime Minister. As he declared, 'by appointing one of the sons of our soil to this important post, the President has scratched our back, and we shall scratch the Head of State's back when the time comes' (Akoko and Mbuagbo 2003:6).

33. See Postwatch, 15 September 2004:3

34. This witticism is in fact a sharp critic against the so-called counter-hegemonic culture. See Frank 1997[1995]:31-45.

35. Cf. Resolutions of the SDF National Executive Committee on 27 October 2002.

36. See Le Messager, June 2001; Mutations, 27 September 2004.

37. See www.sdfparty.org/english/resolutions/345.php, 23 June 2005.

38. Le Messager on line (13 February 2005).

\section{Reierences}

Akoko, M. R. and Mbuagbo, O. T., 2003, 'Motions of support' and Ethno-regional Politics in Cameroon', unpublished paper.

Alima, J. B., 1977, Les Chemins de l'Unité: Comment se forge une nation: L'exemple camerounais, Paris: ABC.

Awasom, N. F., 1999, 'From Migrants to Nationals and from Nationals to Undesirable Elements: The Case of the Fulani (Mbororo) in the Northwest Province of Cameroon', paper presented at the International Colloquium on 'Être Étranger et Migrant en Afrique au XXe siècle', Paris: 9-1 1 December.

Awasom, N. F., 2001, 'Autochthony and Citizenship in Postcolonial Africa: A critical perspective on Cameroon', Leiden: Africa Studies Centre Seminar. 
Azarya, V., 1994, 'Civil Society and Disengagement in Africa', in J. W. Harbeson, D.R. Rothchild, N. Chazan, eds., Civil Society and the State in Africa, Boulder and London: Lynne Rienner, pp. 83-100.

Azarya, V. and Chazan, N., 1987, 'Disengagement from the State in Africa: Reflections on the Experience of Ghana and Guinea', Comparative Studies in Society and History, Vol. 29, No. 1, pp. 106-31.

Badie, B., 1992, L'Etat importé: L' Occidentalisation de l'ordre politique, Paris: Fayard.

Banoch, M., 1992, Le Processus de démocratisation en Afrique: Le cas Camerounais, Paris: L'Harmattan.

Bayart, J.-F., Ellis, S. and Hibou, B., 1999, Criminalization of the State in Africa, London: James Currey.

Bayart, J.-F., 1993, The State in Africa: the Politics of the Belly, trans. by Mary Harper, London and New York: Longman.

Bayart, J.-F., Mbembe, A. and Toulabor, C., 1992, Le Politique par le bas en Afrique noire: Contributions à une problématique de la démocratie, Paris: Karthala.

Bayart, J.-F., 1986, 'Civil Society in Africa', in P. Chabal, ed., Political Domination in Africa: Reflections on the Limits of Power, Cambridge: Cambridge University Press, pp.104-19.

Bratton, M., 1989, 'Beyond the State: Civil Society and Associational Life in Africa', World Politics, Vol. 41, No. 3, pp. 407-29.

Callaghy, M. T., 1994, 'Civil Society, Democracy, and Economic Change in Africa: a Dissenting Opinion about Resurgent Societies', in J. W. Harbeson, D.R. Rothchild, N. Chazan, eds., Civil Society and the State in Africa, Boulder and London: Lynne Rienner. pp. 231-53.

Chabal, P. and Dalloz, D., 1999, Africa Works: Disorder as Political Instrument, Oxford and Bloomington: James Currey/Indiana University Press.

Chabal, P., ed., 1996, Political Domination in Africa: Reflections on the Limits of Power, Cambridge: Cambridge University Press.

Chazan, N. Mortimer, R. Ravenhill, J. and Rothchild, D., 1992, Politics and Society in Contemporary Africa, Boulder, CO: Lynne Rienner Publishers.

Clark, J.F., 1998, 'National Conferences and Democratization in Africa' in J. Mukum Mbaku and J. O. Thonvbere, eds., Multiparty Democracy and Political Change. Constraints to Democratisation in Africa, Aldershot, Brookfeld: Ashate.

Collectif Changer le Cameroun, 1990, Changer le Cameroun: pourquoi pas? Yaounde: Edition c3.

Comaroff, J. and Comaroff, J. L., 2000, 'Millennial Capitalism: The first Thoughts on a Second Coming', in Public Culture, Vol. 12, No 2, pp. 291-343.

Comaroff, J. and Comaroff, J. L., eds., 1999, Civil Society and the Political Imagination in Africa: Critical Perspectives, Chicago: Chicago University Press.

Comaroff, J. and Comaroff, J. L., eds., 1993, Modernity and its Malcontents: Ritual and Power in Postcolonial Africa, Chicago: University of Chicago Press.

Courade, G. and Sindjoun, L., 1996, Le Cameroun dans l'entre-deux, special issue, Politique Africaine, No. 62.

de Boeck, F., 1998, 'Domesticating Diamonds and Dollars: Identity, Expenditure and Sharing in Southwestern Zaire (1984-1997)', in B. Meyer and P. Geschiere, 
eds., Development and Change, Special issue on 'Globalization and Identity: Dialectics of Flows and Closures', Vol. 29, No. 4, pp. 777-809.

Eboussi Boulaga, F., 1993, Les Conférences nationales: Une affaire à suivre, Paris: Karthala.

Fatton, R. Jr., 1987, The Making of a Liberal Democracy: Senegal's passive revolution, 1975-1985, Boulder: Lynne Rienner Publishers.

Ferguson, J., 1999, Expectations of Modernity: Myths and Meanings of Urban Life on the Zambian Copperbelt, Berkeley: University of California Press.

Foucault, M., 1991, 'Governmentality,' in G. Burchell et al., eds., The Foucault Effects, Chicago: University of Chicago Press.

Foucault, M., 1979, Discipline and Punish: The birth of Prison, trans. by Alan Sheridan, New York: Vintage/Random House.

Frank, A.G., 1991, 'No. Escape from the Laws of World Economics,' in Review of African Political Economy, Vol. 50, pp. 21-32.

Frank, T., 1997[1995], 'Why Johnny can't Dissent?' in T. Frank, and M. Weiland, eds., Commodify your Dissent: Salvos from the Baffler, New York: Norton, p.31-45

Geschiere P. and Njamnjoh, F.B., 2000, 'Capitalism and Autochthony: the Seesaw of Mobility and Belonging', in Public Culture, Vol. 12, No. 2, pp. 423-452

Habermas, J., 1984, The Theory of Communicative Action. Vol. I, Of Reason and the Rationalization of Society, trans. by Thomas McCarthy, Boston: Beacon Press.

Habermas, J., 1989, The Structural Transformation of the Public Sphere. An Inquiry into a Category of Bourgeois Society, Cambridge: Cambridge University Press.

Harbeson, J. W., 1994,' Civil Society and Political Renaissance in Africa' in J.W. Harberson, and D. R. Rothchild, and N. Chazan, eds., Civil Society and the State in Africa. Boulder and London: Lynne Rienner Publishers, pp.1-29.

Harbeson, J. W., Rothchild, D. R., and Chazan, N., eds., 1994, Civil Society and the State in Africa, Boulder and London: Lynne Rienner Publishers.

Harbeson, J. W. and Rothchild, D. R., eds., 1991, Africa in World Politics, Boulder: Westview Press.

Hermet, G., 1998, La Trahison démocratique: politiques républicaines et démocrates, Paris : Flammarion.

Hibou, B., ed., 1999, La privatisation des Etats, Paris: Karthala

Hibou, B., 1998, 'The Political Economy of the World Bank's Discourse: From Economic Catechism to Missionary Deeds (and Misdeeds)', Les Etudes du CERI, Vol. 39

Jaffrelot, C., eds., 2000, Démocraties d'ailleurs. Paris: Karthala.

Joseph, R. 1977. Radical Nationalism in Cameroon. Social Origins of the UPC Rebellion, Oxford: Oxford University Press.

Jewsiewicki, J., 1992, 'Jeux d'argent et de pouvoir au Zaire: La 'bindomanie' et le crépuscule de la deuxième République', Politique Africaine, Vol. 46.

Kamto, M., 1997, 'Les Conférences nationales africaines ou la création révolutionnaire des constitutions', in D. Darbon, and J. du Bois de Gaudusson, eds., La Création du droit en Afrique, Paris: Karthala, pp. 177-96.

Kegne Pokam, J.-P., 1986, La problématique de l'unité nationale au Cameroun: Dichotomie entre discours et pratiques dans un système monolithique, Paris: L' Harmattan. 
Konings, P., 2001, 'Mobility and Exclusion: Conflicts Between Autochthons and Allochthons during the Political Liberalization in Cameroon', in M. de Bruijn, R. van Dijk and D. Foeken, eds., Mobile Africa: Changing Patterns of Movements in Africa and Beyond, Leiden: Brill, pp. 169-94.

Konings, P., 2002, 'University Students Revolt, Ethnic Militia and Violence During Political Liberalism in Cameroon', in African Studies Review, Vol. 45, No. 2, pp. 179-204.

Konings, P. and Nyamnjoh, F. B., 1997, 'The Anglophone Problem in Cameroon' in The Journal of Modern African Studies, Vol. 35, No. 2, pp. 207-29.

Konings, P. and Nyamnjoh, F. B., 2000, 'Construction and Deconstruction: Anglophones or Autochthons'? in The African Anthropologist, Vol. 7, No. 1, pp. 5-32.

Konings, P. and Nyamnjoh, F. B., 2003, Negotiating Anglophone Identity: A Study in the Politics of Recognition and Representation in Cameroon, Leiden: Brill.

Le Quotidien, 1998, 'Les Villes-mortes de 1991: Le feu, Les Casses, les Morts’, 2931 May.

Markovitz, I. L., 1987, Studies of Power and Class in Africa, New York: Oxford University Press.

Mbaku, J. M., 2002, 'Cameroon's Stalled Transition to Democratic Governance: Lessons for Africa's New Democrats', in Africa and Asia studies, Vol. 1, No. 1, Leiden: Brill.

Mbarga, Ndi, 1993, Ruptures et continuité au Cameroun, Paris: L'Harmattan.

Mbembe, A., 2001, On the Postcolony, Berkeley: University of California Press.

Mbembe, A., 1996, La Naissance du Maquis dans le Sud-Cameroun: Histoire d'indisciplines, Paris: Karthala

Mbembe, A., 1993, 'Crise de légitimité, restauration autoritaire et déliquescence de 1 'Etat,' in P. Geschiere and P. Konings, eds., Itinéraires d'accumulation au Cameroun/Pathways to Accumulation in Cameroon., Leiden/Paris: ASC/Karthala, pp. 345-74.

Mbuagbo, O. T. and Akoko, M. R., 2004, 'Roll-Back: Democratization and Social Fragmentation in Cameroon', in Nordic Journal of African Studies, Vol. 13, No. 1, pp. 1-12.

Monga, C., 1995, 'Civil society and democratisation in Francophone Africa', The Journal of Modern African studies, Vol. 33, No. 3, pp. 359-79.

Monga, C., 1997, 'Cartoons in Cameroon: Anger and Political Derision under monocracy', in Anyidoho, K., ed., The Word Behind the Bars and the Paradox of Exile, Evanston, Illinois, Northwestern University Press, , pp. 146-69.

Monga, C., 1998, Anthropology of Anger. The Civil Society and Democracy in Africa, Boulda, Co: Lynne Rienner Publishers.

Mono Djana, H., 1999, Le temps des Clarifications, Yaounde: Liberté.

Mono Djana, H., 1992, La Mutation: Essai sur le changement politique au Cameroun, Yaounde/Bruxelles: Carrefour/Y. Priguot.

Mono Djana, H., 1997, Les Proverbes de Paul Biya., Yaounde: Carrefour.

Mpom, I., 1994, 'Indocilité géneralisée', in Génération, No. 2, p. 4. 
Mukum Mbaku, J. and Ihonvbere, J. O., eds., 1998, Multiparty Democracy and Political Change. Constraints to Democratisation in Africa, Aldershot, Brookfeld: Ashate.

Ndedi Penda, P., 1992, Le Pouvoir aux deux visages: La Terreur et la Prospérité, Douala: Publications Galaxie.

Ndjio, B., 2002, 'Space of pleasure and practice of ungovernmentality in the Postcolonial Africa', paper presented during the Conference on 'Mediatizing the public sphere', Amsterdam, 3 May.

Ndjio, B., 2005, 'Carrefour de la joie: Popular deconstruction of the African postcolonial public sphere', in Africa, Vol. 75, No. 3, pp. 265-94.

Ngniman, Z., 1998, Paul Biya: La Magistrature présidentielle apaisée? Yaoundé: Edit'action.

Nyamnjoh, F. B., 1998, 'Media Ownership and Control in Cameroon: Constraints on Media Freedom', in Media Development, Vol. XLV, No. 4, pp. 29-35.

Nyamnjoh, F. B., 1999, 'Press Cartoons and Politics in Cameroon' in Cahier de L'UCAC, No. 2, pp. 93-106.

Nyamnjoh, F. B., 2000, 'For many are called but few are chosen: Globalisation and Popular Disenchantment in Africa', in African Sociological Review/Revue Africaine de Sociologie, Vol. 4, No. 2, p. 1-44.

Nyamnjoh, F. B., 2004, 'Cameroon: over twelve years of cosmetic democracy', paper presented at the Nordic Africa Institute, December.

Nyanmjoh, F. B. and Fokwang, J., 2003, 'Politics and Music in Cameroon', in J.-G. Gros, ed. Cameroon: Politics and Society in Critical Perspective, Lanham: University Press of America, pp. 185-208.

Nyang'oro, J. E., 1994, 'Reforms, Politics and Democratization process in Africa', in African Studies Review, Vol. 37, No. 1, pp. 133-49.

Nzouankeu, J. M., 1993, 'The role of the National Conference in the Transition to Democracy in Africa: The cases of Benin and Mali,' Special Issue, A Journal of Opinion, Vol. 21, No.1-2, pp. 44-50.

O’Donnell, G. and Schnitter, P., 1989, Transitions from Authoritarian Rule: Tentative Conclusions about Uncertain Democracies, Baltimore: Johns Hopkins Press. Politique Africaine, Vol. 42, No. 2, 1991, Pouvoir et Violence, special issue.

Rothchild, D. R. and Chazan, N., eds., 1988, The Precarious Balance: State and Society in Africa, Boulder: Westview Press.

Rush, J., 1990, Opium to Java: Revenue Farming and Chinese Enterprise in Colonial Indonesia, 1860-1910, Ithaca, NJ: Cornell University Press.

Sindjoun, L., 1996, 'Le Champ social camerounais:désordre inventif, mythes simplicateurs et stabilité hégémonique de l'Etat', in Politique Africaine, Vol. 62, No. 1, pp. 27-51.

Sindjoun, L. and Owona Nguini, E. M. 1997, 'Politisation du droit et juridicisation de la politique: l'esprit sociologique du droit de la transition démocratique au Cameroon', in D. Darbon and J. du Bois de Gaudusson, eds. La Création du droit en Afrique, Paris: Karthala, pp. 217-245.

Schatzberg, M. G., 1993, 'Power, legitimacy and « democratisation » in Africa,' Africa, Vol. 61, No. 4, pp. 445-61. 
Scott, J., 1990, Domination and the Arts of Resistance. Hidden Transcripts, New Haven and London: Yale University Press.

Scott, J., 1985, Weapons of the Weak: Everyday Forms of Peasant Resistance, New Haven: Yale University Press.

Socpa, A., 2002, 'Démocratisation et autochtonie au Cameroun: Trajectoires régionales divergentes', $\mathrm{PhD}$ Dissertation, CNWS/ University of Leiden Spivak C. G., 1985, 'Subaltern Studies: Deconstructing Historiography', in R. Guha, ed., Subaltern Studies IV: Writings on South Asian History and Society, Oxford: Oxford University Press, pp.330-63.

Stallybrass, P. and White, A., 1989, The politics and Poetics of Transgression, Ithaca, N.Y: Cornell University Press.

Takougang, J. and Krieger, M., 1998, African State and Society in the 1990s: Cameroon Political Crossroads, Oxford, Westview Press.

Tenfack, O., 1994, Postwatch on line, 15 September.

Toulabor, C., 1991, 'Jeux de mots, jeux de vilain: Lexique de la dérision politique au Togo', in Politique Africaine, No. 3, pp. 55-71.

Touraine, A., 1992, Critique de la Modernité, Paris: Fayard.

Um Nyombe R., 1989, Ecrits sous le Maquis, edited by J. A. Mbembe. Paris: L'Harmattan.

Um Nyombe R., 1984, Le Problème national Camerounais, edited by A. Mbembe, Paris: L'Harmattan.

Van der Walle, N., 1990, 'The Politics of Non-Reforms in Cameroon,' African governance in the 1990s: Objectives, Resources and Constraints, Working paper of the second annual Seminar of the African governance program, The Carter Center of Emory University, Atlanta, Georgia, March 23.

World Bank Report, 1989, From Crisis to a sustainable Development, Washington DC. 